WHOI $-82-8$

\title{
A SELF-POWERED PUMPING SYSTEM FOR IN SITU EXTRACTION OF PARTICULATE AND DISSOLVED MATERIALS FROM LARGE VOLUMES OF SEAWATER
}

by

Clifford L. Winget, John C. Burke, David L. Schneider and Don R. Mann

\author{
WOODS HOLE OCEANOGRAPHIC INSTITUTION \\ Woods Hole, Massachusetts 02543
}

February 1982

TECHNICAL REPORT

Prepared for the U.S. Department of Energy under Contracts $D E-A C 02-76 E V 03563$ and DE-AC02-81EV10694 and through Sandia Laboratomies under Contracts 13-2562 and 16/3112.

Reproduction in whole or in part is permitted for any purpose of the United States Govermment. This report should be cited as: Woods Hole Oceanog. Inst. Rept. WHOI-82-8.

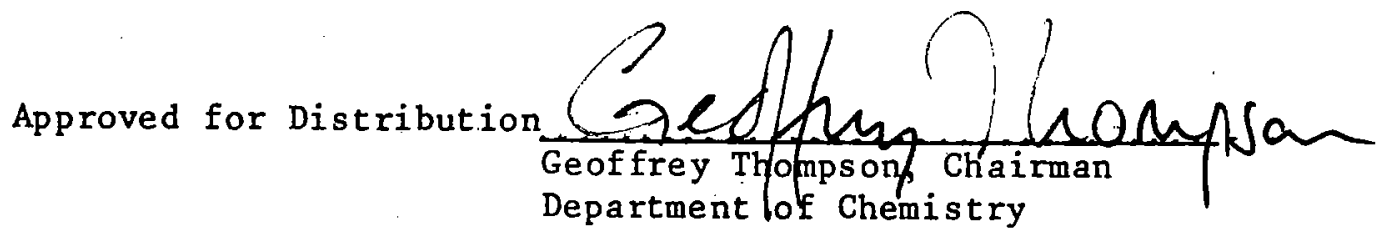


A pumping system has been developed for the in situ extraction of particles and of dissolved constituents from large volumes of seawater. The assembly consists of a battery-powered submersible pump, filters, and chemisorptive cartridges; it is entirely self-contained and has been used successfully on ship's hydrographic wire to depths as great as $5800 \mathrm{~m}$. The pump is designed to operate at a maximum pressure drop of $66 \mathrm{~cm}$ of $\mathrm{Hg}$; flow rates have varied from 1.3 to 5.1 liters/min. We have sampled volumes as large as 758 liters, and the measured battery drain suggests that volumes severa 1 times this could be pumped at any depth. The system is being used to study a variety of artificial radionuclides, but modifications of the filter or chemisorbent units would make it useful in many other geochemical applications. 


\section{Introduction}

Radionuclides from either natural or artificial sources have proved valuable tracers of a variety of oceanographic processes. The nuclide concentrations to be measured are, however, of ten very low, so that the determination of their water column distributions has entailed sampling large volumes of water to achieve acceptable confidence limits, especially in the estimation of important nuclide ratios. A variety of water samplers with capacities ranging from 150 to 220 liters, operated either from hydrographic or trawl wire, have been described; the two most widely used are those of Bodman et a1. (1961) and Gerard and Ewing (1961). Larger volume samplers have been attempted, but have consistently proved unreliable because of handling difficulty.

For sampling volumes in the 500 to several thousand liters range, pumping has been the most successful approach. Either submersible (Jeffrey et al., 1973) or deck-mounted (Silker et al., 1971) pumps have been used with hoses to deliver large volumes of water, on deck, for storage or for immediate chemical processing. Cost and handling problems have, however, limited hose-collecting to the upper parts of the water column. Both this consideration and the conviction that physical-chemical speciation of the tracers sought sometimes will be altered during the changes incident to delivery of water samples to the surface have led our research team to emphasize in situ separation and concentration of the tracers sought. This approach to particle collection has been reported by Spencer and Sachs (1970), Beer et al. (1974), Bishop and Edmond (1976) and Krishnaswami et al. (1976), using either battery-powered pumps or devices supplied by power-cables from the ship. Another pump mechanism has been described by Hess (1977). 
For non-particulate tracers our emphasis has been on the use of specific chemisorptive cartridges as described by Wong et al. (1978) for actinides and by Folsom et $\mathrm{al}$. (1975) for radiocesium. The details of the radionuclide collecting methods, their efficiencies and applications, are being prepared for publication elsewhere. In this report we describe the relative 1y inexpensive, battery-powered, hydrographic-wire-mounted electric pump and housing that we have developed; it will be clear, we believe, that this unit has much wider adaptability than just for the collection of radionuclide tracers.

Our selection of battery power, over reliance on the use of conducting cable, was based on the following considerations:

(a) Sampling flexibility, that permits the use of vessels of opportunity, is important in our program; the pumping system should not be limited by the conducting cable capability of a vessel.

(b) Since chemisorption efficiencies often require rather slow pumping rates, optimum use of ship time suggests that multiple unit deployment will be important.

(c) The chemical problems of special collections may require rapid changes of suspension cable properties: organic for trace metals, unlubricated metal for trace organics, etc.

\section{Design}

The self-contained, in situ pumping system (Fig. 1) consists of (1) a pressure resistant cylindrical aluminum battery case, (2) a D.C. electric motor housed in an oil-filled pressure compensation container, (3) a rubber impeller pump assembly and (4) a filtration/chemisorption system coupled to 


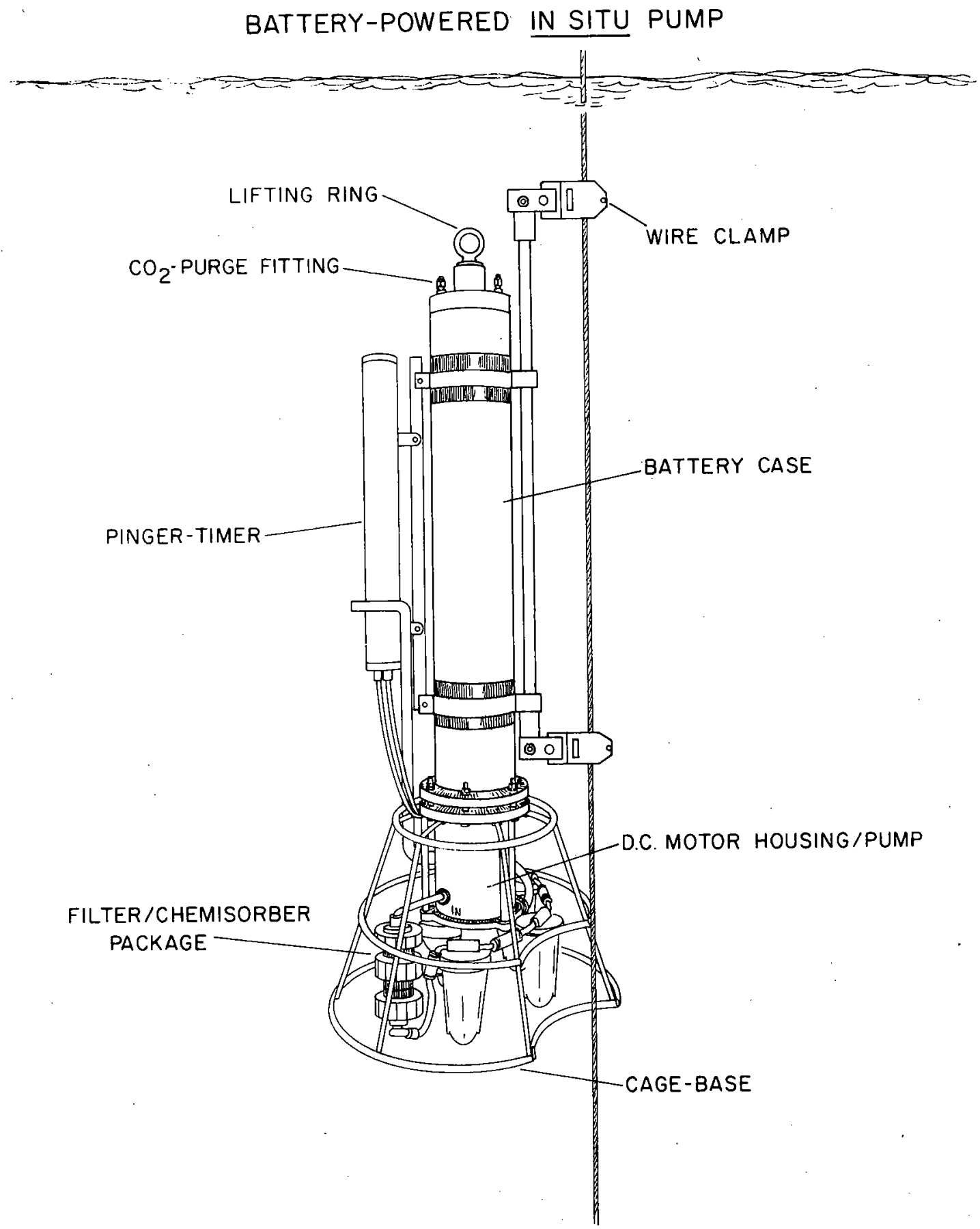

FIGURE 1 
a totalizing flow meter. A separate (5) pinger-timer unit is used to control pump operation during the sampling phase.

The D.C. power source consists of six spil1-proof lead-acid storage batteries (Eag1e-Picher Industries, Inc., Seneca, M0; type CF6V15; $9.2 \mathrm{~cm} \times$ $8.4 \mathrm{~cm} \times 16.5 \mathrm{~cm})$. Each battery has a six-vo1t potential with a rated capacity of 13 amps at a five hr rate. They are wired in a series/paralle1 arrangement, providing an output of 18 volts. As a close coupled stack held firmly in a squirrel-cage frame, they form a convenient package that slides into the $15 \mathrm{~cm}$ I.D. pressure housing. The present system configuration draws 3.5 to 4.0 amps when pumping, with the total battery drain depending on the length of time the motor is in operation. Laboratory tests have shown that a continuous pump cycle in excess of eight hours can be expected before decrease in the battery voltage causes any degradation of the pump rate. Two battery packs are used, providing the capability of having one on charge while the other is operational. The recharge cycle is a $12 \mathrm{hr}$ current-1imited taper charge. Started at 3.6 amps at 22.5 volts, the current and voltage readings decrease to approximately 100 milliamps and 19 volts at the completion of the cycle. Charging must occur with the battery pack removed from the housing and located in a well-vented area. Hydrogen gas expelled from the cells could result in an explosive atmosphere if the batteries were recharged within the pressure case. In an emergency, a battery pack can in four hours be recharged to $90 \%$ of its rated capacity. The motor used to drive the pump is a model T06LB permanent-magnet, direct current device manufactured by PMI Kollmorgan Corp., Syosset, NY, and is rated at $24 \mathrm{VDC}$ at 5.6 amps with a torque of $9937 \mathrm{~g}-\mathrm{cm}$. It is mounted in an aluminum housing filled with a low viscosity compensation oil, $\mathrm{C}-141$, made 
by Royal Lubricant Co., Hanover, NJ. When the housing is connected to an external bladder, the internal housing pressure always equals the external water pressure, regardless of depth. This method of pressure balancing a system permits the use of relatively lightweight, thin-walled motor housings that do not have to resist the pressure of great ocean depths, and facilitates the design of shaft seals for rotary drives that pass through the walls of a chamber. A carbon-ceramic face seal provides the barrier between the compensation fluid and the external seawater at the point where the motor drive shaft passes through the housing and enters the pump.

The pump is a modified Jabsco Products assemb1y P/N 17000-0001. It consists of a molded epoxy housing and neoprene impeller mounted externally to the pressure-compensated housing of the drive motor. In this configuration, the pump is readily accessible for maintenance and impeller replacement. It is positioned downstream of the filter and chemisorptive cartridge assembly, operating in the suction mode, to reduce the possibility of sample contamination. The discharge of the pump is directed away from the general area of the filter inlet to assure that the incoming sample has not been mixed with fluid that has already passed through the system.

The filter/chemisorption system includes a one-micron prefilter (AMF Cuno; Microwynd II cartridge; type 1 M housing) and a series of chemically loaded cartridges: $\mathrm{MnO}_{2}$ type for the sorption of actinides, lanthanides and radioiron and/or $\mathrm{Cu}_{2} \mathrm{Fe}(\mathrm{CN})_{6}$ type for radiocesium. The volume of water passing through the system is measured with a positive displacement, piston type totalizing flow meter (Kent Meter Sales, Ocala, FL; model PSM 190) with a rated accuracy of $1.5 \%$ at flow rates down to 0.51 iters/min. Water moves through the system in the sequence: prefilter, cartridges, pump 
and flow meter (Fig. 2); the maximum flow rate with both types of chemisorbers employed is approximately three 1 iters/min at a reasonably constant negative pressure of $66 \mathrm{~cm}$ of mercury.

A stainless steel cage provides a stand for the complete assembly as well as a protective shield for the cartridges and flow meter.

The pump does not operate during transit through the water column but is turned on and off at depth by a pinger-timer (Oceanographic Instrument Systems, North Falmouth, MA). Microswitches within the pinger allow pre-selection of pumping intervals up to a maximum of 42 hours. In the present configuration, battery current to the motor is controlled by a remote relay contained in the pinger package; potentially an overload of the relay contacts could damage the pinger control circuitry. In the future, a separate relay, with contacts capable of withstanding the motor load, will be mounted within the oil-filled motor housing. The original control relay in the pinger will be used to operate the new power relay control solenoid. The entire assembly weighs $106 \mathrm{~kg}$ in air and has an overal1 length of $1.8 \mathrm{~m}$. The battery case is $18 \mathrm{~cm} 0 . \mathrm{D}$. and the cage-base is $60 \mathrm{~cm}$ at its largest diameter.

\section{Assemb1y and Operation}

The motor housing with attached pump is first secured to the base. The battery pack then mounts to the motor housing end plate with three quartertwenty bolts. Electrical connection with the pump motor is made by inserting Mecca plugs from the pack into terminal holes in the end plate of the motor housing. The pressure case enclosing the batteries is then attached to the end plate with $1.3 \mathrm{~cm}$ diameter stainless steel bolts; two Buna $\mathrm{N}$ 0-rings make a water tight seal between the two units. Prior to sea trial, the 


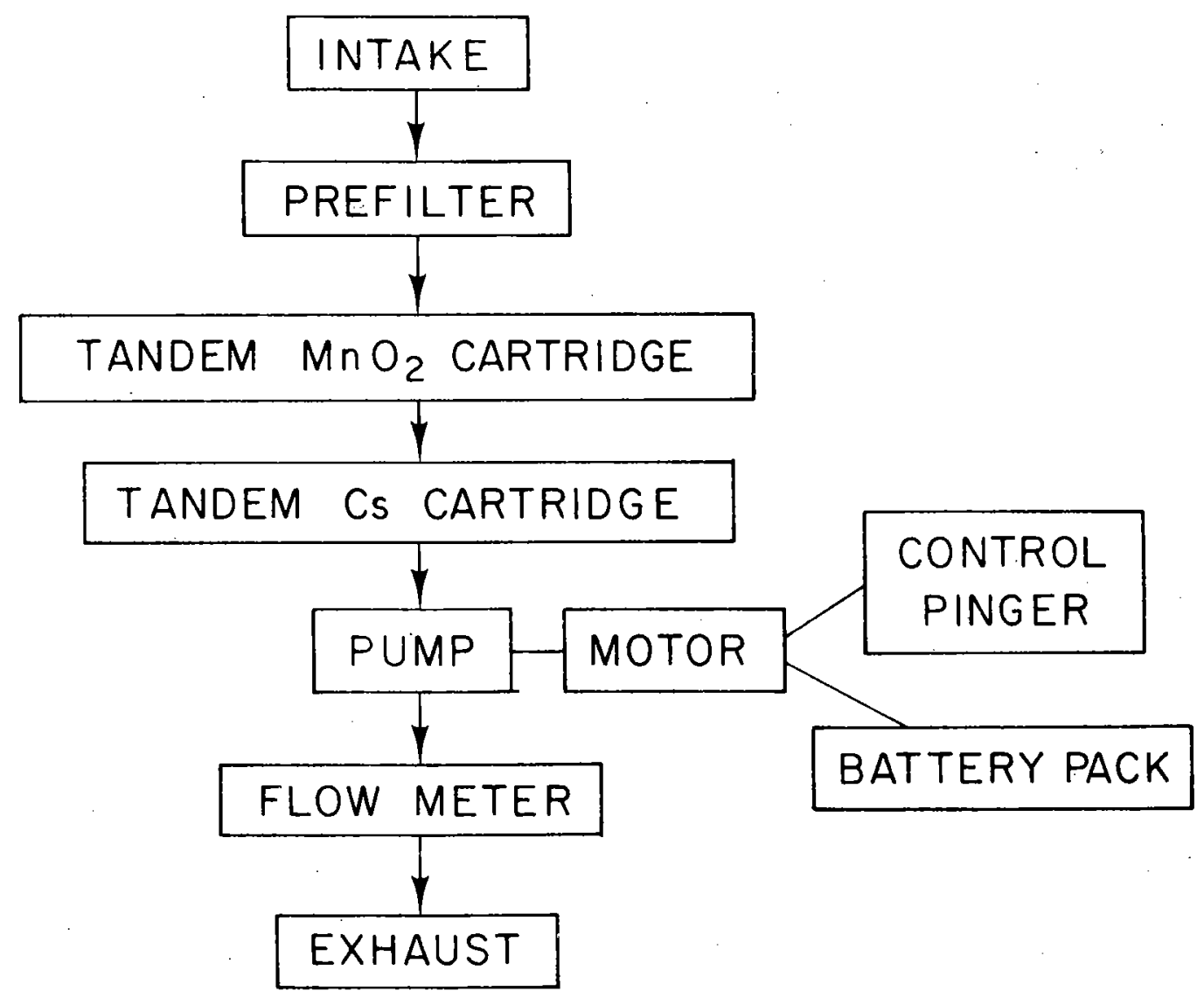

FIGURE 2 
device was satisfactorily pressure tested to a rated $6000 \mathrm{~m}$ depth at Benthos, Inc., North Falmouth, MA.

Before deployment, as a precaution against the buildup of an explosive mixture from battery-vented hydrogen, the battery case is purged with inert gas. Several methods and types of inert gases are available for backfilling the chamber, and are quite acceptable. We chose to use $\mathrm{CO}_{2}$ cartridges from scuba-diving flotation vests. Two fitting caps at the top of the battery case are removed and a $\mathrm{CO}_{2}$ charge adapter secured to one of the fittings. The $\mathrm{CO}_{2}$ cylinder is discharged into the chamber with displaced gases flowing out the open fitting. After total discharge of the $\mathrm{CO}_{2}$, the fitting caps are secured and made watertight.

The pinger is attached to the pump and is electrically coupled to the pump motor by Mecca connectors at terminal pins located in the impeller end of the motor housing. With the cartridge-flow meter package secured, filled with distilled water, and connected to the pump with plastic tubing, the entire assembly is hoisted by the lifting ring at the top and attached to the weighted hydrowire by two split clamps mounted on the clamp bar.

During descent to sampling depth, a single ping is monitored on the ship's depth recorder; the bottom reflection from this signal is used to position the pump at near-bottom stations. A Nansen bottle with reversing thermometers, attached to the wire just above the pump, is tripped before the pumping period ends. Verification of depth is made from thermometric calculation and salinity measurement. Confirmation of an ON signal sent to the pump is made by the pinger changing to a double ping signal; a return to single ping mode verifies termination of the pumping cycle. 
Upon recovery of the sampler, the battery pack is removed for recharging, and the filter and chemisorbers are transferred to plastic bags or bottles for future radiochemical analyses.

\section{Results and Discussion}

Concentration determinations of either particulates or dissolved tracers demand accurate measurement of the water volume passed through the filter/ chemisorber system. For this reason, the flow meter is an important component of any in situ pumping system. In a laboratory test of reproducibility and accuracy, three kent meters were connected in series to a faucet. The flow rate was adjusted to $2.5 \mathrm{liters} / \mathrm{min}$ (the rate at which our cartridge performance is optimum) and the reading of each flow meter recorded at the beginning and end of one hour. The results, presented in Table 1, demonstrate adequate reproducibility; the accuracy of the meters for 150 liters is within the $\pm 1.5 \%$ accuracy specified by the manufacturer. Since the glycol and water-filled register is the only enclosed part, the meters' internal and external surfaces are subjected to equal pressure at depth; we have no test data relating meter performance to pressure and temperature extremes.

The prototype pump assembly was first used at sea on $R / V$ THOMAS WASHINGTON, Cruise RAMA O2 (Honolulu-Midway; May, 1980) with results shown in Table 2. With just one pump, only a single lowering was made per station. At station 111 , seawater leaked into the battery case through an improperly seated fitting cap, shorting out the batteries and stopping the pump at some indeterminate time during the pumping period. Flow rates at the remaining stations varied from 1.3 to 5.1 liters/min. This is a reasonable range for a chemisorption system where the efficiency of nuclide extraction is expected 
TABLE 1. COMPARISON OF THREE KENT FLOW METERS CONNECTED IN SERIES.

Meter Number

1

2

3
Volume Measured*

$$
\begin{aligned}
& 149.5 \underline{1} \\
& 148.4 \underline{1} \\
& 147.6 \underline{1}
\end{aligned}
$$

\begin{tabular}{|c|c|c|c|c|c|}
\hline $\begin{array}{l}\text { Station } \\
\text { Number }\end{array}$ & $\begin{array}{l}\text { Samp le } \\
\text { Depth } \\
(\mathrm{m})\end{array}$ & $\begin{array}{l}\text { Temp. } \\
\left({ }^{\circ}{ }_{C}\right) \\
\end{array}$ & $\begin{array}{l}\text { Pumping } \\
\text { Interval } \\
(\mathrm{hr}) \\
\end{array}$ & $\begin{array}{c}\text { Total } \\
\text { Volume } \\
(1) \\
\end{array}$ & $\begin{array}{l}\text { Flow } \\
\text { Rate } \\
(1 / \mathrm{min}) \\
\end{array}$ \\
\hline 111 & $300^{*}$ & 11.09 & -- & 163 & -- \\
\hline 142 & $550^{*}$ & 6.23 & 2.5 & 329 & 2.2 \\
\hline 161 & $550^{+}$ & 6.23 & 2.5 & 758 & 5.1 \\
\hline 153 & $750^{*}$ & 4.30 & 2.5 & 195 & 1.3 \\
\hline 177 & $3000^{*}$ & 1.59 & 7 & 654 & 1.6 \\
\hline 165 & $5600^{+}$ & 1.61 & 5 & 633 & 2.1 \\
\hline 162 & $5800^{+}$ & 1.62 & 5 & 592 & 2.0 \\
\hline
\end{tabular}

* F low rate maintained at $2.5 \underline{1} / \mathrm{min}$ for one hour. Tap water at about $5^{\circ} \mathrm{C}$.

TABLE 2. SAMPLING PARAMETERS AND PUMPING RATES IN SITU; FIELD DEPLOYMENT.

*Prefilter, $2 \mathrm{MnO}_{2}$ and $2 \mathrm{Cs}$ cartridges.

+ Prefilter and $2 \mathrm{MnO}_{2}$ cartridges. 
to be directly related to the exposure time of seawater to the sorber material. It is low enough to give good nuclide retention while still permitting large volumes to be sampled in a reasonable amount of station time. The indicated retention efficiencies of the prefilter and chemisorber cartridges are discussed elsewhere (Wong et a1., 1978; Mann and Casso, submitted). When stations 142 and 161 are contrasted, it is clear that the Cs cartridges substantially increased the resistance of the chemisorption package, thereby reducing the flow rate; this was expected from laboratory tests. In fact, the resistance effect due to the Cs sorber units appears to be the over riding factor affecting flow rate when both $\mathrm{Cs}$ and $\mathrm{MnO}_{2}$ cartridges are employed. A depth effect due to temperature and/or pressure is not clearly drawn from the results. Recalling that 3.01 iters/min is the maximum flow rate expected with both kinds of cartridges in series, a depth effect at stations 142,153 and 177 does not appear significant in controlling the rate. A comparison of station 161 with stations 162 and 165 suggests, however, that with only the lower resistance $\mathrm{MnO}_{2}$ cartridges in 1 ine, a depth effect may be important in controlling flow rate. The rate on the two deep casts was consistent and about $2-1 / 2$ times 1 ower than the rate at $550 \mathrm{~m}$. The decrease could indicate reduced operating efficiency of the system in response to temperature and/or pressure; however, these factors must be. secondary to Cs cartridge resistance in controlling the flow rate. Some variance in flow rate is almost certainly caused by physical differences in individual cartridges or their loading.

Extrapolating from the data in Table 2, it can be estimated that a deep 1000 liter sample, with all cartridges in line, could be collected in approximately twelve to fifteen hours. This should be within the capability of the system, even though the longest pumping interval yet tried was seven hours. 
The battery pack potential at the completion of station 177 was 17.7 volts or $98 \%$ of the full charge potential. A 1000-1iter sample would be more than an order of magnitude increase in sample volume over our usual 50-1iter analytical sample. This should, even with moderate sorption efficiency, be large enough to make a significant improvement in radionuclide measurement sensitivity, particularly with respect to important nuclide ratios. More productive use of ship time could be made by simultaneously deploying several pumps for water column profiling.

Modification of the pump to prevent mechanical binding of the rubber impeller by the squeeze of the pump end cap is contemplated. One failure of the system was traced to this problem. Pending a review of manufacturing tolerances, the proposed solution would be the emplacement of a metallic spacer between the pump housing and the end cap.

The installation of a water-flow sensing switch to verify water movement through the pump assembly is also proposed. At present, the pinger sends a double pulse to the surface vessel verifying that power has been provided to the pump motor. There is no signal to indicate the apparatus has actually started to pump. In the impeller binding case mentioned above, valuable station time could have been saved by knowledge of the pump failure.

\section{Conclusions}

The new in situ pumping system is a relatively compact and inexpensive, easy-to-operate assembly that can be used in both saline and fresh water from any vessel with a hydrowinch and suitable wire rope capability. It is a completely self-contained, battery-powered instrument that has pumped large volumes of seawater at sampling depths approaching $6000 \mathrm{~m}$. The prototype assembly was designed to be used with sorption cartridges specific for the extraction of radiocesium and actinides. However, within the constraints 
of a 3 liter/min maximum flow rate and a negative pressure drop of $66 \mathrm{~cm}$ of mercury, filter/chemisorber units could be developed for the extraction of a wide variety of constituents from natural waters. Optimally, several pumps could be deployed at different intervals on a single cable to sample different parts of the water column simultaneously, making efficient use of costly ship time.

Acknowledgements: It is our pleasure to acknowledge the assistance of David H. Graham in laboratory assembly and testing; the help of William R. Clarke, Joanne E. Goudreau and, particularly, the technical assistance of Douglas E. Moore in testing the prototype pumping system at sea. We especially thank Vaughan T. Bowen both for his support of this project and his criticism of the manuscript. 


\section{REFERENCES}

Beer, R. M., J. P. Dauphin and T. S. Sholes. 1974. A deep-sea in situ suspended sediment sampling system. Mar. Geol., 17, M35-M44.

Bishop, J.K.B. and J. M. Edmond. 1976. A new large volume filtration system for the sampling of oceanic particulate matter. J. Mar. Res., 34(2), $181-198$.

Bodman, H., V. and V. T. Bowen. 1961. A multipurpose large volume seawater sampler. J. Mar. Res., 19(3), 141-148.

Folsom, T. R., N. Hansen, T. J. Tatum and V. F. Hodge. 1975. Recent improvements in methods for concentrating and analyzing radiocesium in seawater. J. Radiation Res., 16(1), 19-27.

Gerard, R. and M. Ewing. 1961. A large volume water sampler. Deep-Sea Res., $8,298-301$.

Hess, F. R. 1977. Stream powered, large volume deep ocean sampler. Woods Hole Oceanographic Institution Invention Disclosure 214-ERDA Docket $S-47,453$.

Jeffrey, L. M., A. D. Fredericks and E. Hi11ier. 1973. An inexpensive deepsea pumping system. Limnol. Oceangr., 18, 336-340.

Krishnaswami, S., D. La1, B.L.K. Somayajulu, R. F. Weiss and H. Craig. 1976. Large-volume in situ filtration of deep Pacific waters: mineralogical and radioisotope studies. Earth P1anet. Sci. Lett., 32, 420-429.

Mann, D. R. and S. A. Casso. In situ chemisorption of radiocesium from seawater-modified methodology. Submitted to Marine Chemistry. Silker, W. B., R. W. Perkins and H. G. Rieck. 1971. A sampler for concentrating radionuclides from natural waters. Ocean. Engng., 2, 49-55. 
Spencer, D. W. and P. L. Sachs. 1970. Some aspects of the distribution, chemistry and mineralogy of suspended matter in the Gulf of Maine. Mar. Geol. , 9, 117-136.

Wong; K. M., G. S. Brown and V. E. Noshkin. 1978. A rapid procedure for plutonium separation in large volumes of fresh and saline water by manganese dioxide coprecipitation. J. Radioanal. Chem., 42, 7-15. 


\begin{tabular}{|c|c|}
\hline $\begin{array}{l}\text { REPORT DOCUMENTATION } \\
\text { PAGE }\end{array}$ & 3. Reciplent's Accession No. \\
\hline 4. Titio and subtitle & 5. Report Date \\
\hline \multirow{2}{*}{$\begin{array}{l}\text { A SELF-POWERED PUMPING SYSTEM FOR IN SITU EXTRACTION OF PARTI- } \\
\text { CULATE AND DISSOLVED MATERIALS FROM LARGE VOLUMES OF SEAWATER }\end{array}$} & February 1982 \\
\hline & 6. \\
\hline $\begin{array}{l}\text { Author(s) Cl i fford L. Winget, John C. Burke, David L. Schneider } \\
\text { and Don R. Mann }\end{array}$ & 8. Performing Organization Rept. No. \\
\hline 9ertormine Orcenization Name and Addrass & 10. Project/Task/Work Unit No. \\
\hline $\begin{array}{l}\text { Woods Hole Oceanographic Institution } \\
\text { Woods Hole, Massachusetts } 02543\end{array}$ & $\begin{array}{l}\text { 11. Contract(C) or Grant(G) No. } \\
\text { (c)DE-ACO2-76EV03563 } \\
\text { DE-ACO2-81EV } 10694 \\
\text { (G) } 3562 \text { and } 16 / 3112\end{array}$ \\
\hline 12. Sponsorine Organization Name and Address: & 13. Type of Report \& Perlod Covered \\
\hline \multirow{2}{*}{$\begin{array}{l}\text { U.S. Department of Energy } \\
\text { Sandia Laboratories }\end{array}$} & Technical. \\
\hline & 14. \\
\hline
\end{tabular}

\section{Supplementary Notes}

This report should be cited as: Woods Hole Oceanog. Inst. Tech. Rept. WHOI-82-8.

\section{Abstract (Limit: 200 words)}

A pumping system has been developed for the in situ extraction of particles and of dissolved constituents from large volumes of seawater. The assembly consists of a battery-powered submersible pump, filters, and chemisorptive cartridges; it is entire-

- ly self-contained and has been used successfully on ship's hydrographic wire to depths as great as $5800 \mathrm{~m}$. The pump is designed to operate at a maximum pressure drop of $66 \mathrm{cu}$ of $\mathrm{Hg}$; flow rates have varied from 1.3 to 5.1 liters/min. We have sampled volumes as large as 758 liters, and the measured battery drain suggests that volumes several times this could be pumped at any depth. The system is being used to study a variety of artificial radionuclides, but modifications of the filter or chemissorbent units would make it useful in many other geochemical applications.

7. Document Analysis o. Descriptors

1. Pumping system-battery powered.

2. Water sampling-large volume

3. In situ

b. Identlfiers/Open-Ended Terms

c. COSATI Field/Group

I Avallability Statement

19. Security Class (This Report)

UNCLASSIEIED

20. Security Class (This Page)
21. No. of Pages $-76$ 